
\title{
Research Suare \\ Development of a robust method for propagation of Leptospermum scoparium J.R.Forst. \& G.Forst. from semi-hardwood cuttings
}

Methodology

Keywords:

Posted Date: November 16th, 2020

DOl: https://doi.org/10.21203/rs.3.rs-83258/v2

License: (c) (i) This work is licensed under a Creative Commons Attribution 4.0 International License.

Read Full License 


\section{Abstract}

The authors have requested that this preprint be withdrawn due to erroneous posting.

\section{Full Text}

The authors have withdrawn this preprint from Research Square. 